\title{
Kunstvarket i dets tekniske reproducerbarheds tidsalder
}

\begin{abstract}
Vore skønne kunster blev grundlagt og deres forskellige typer såvel som deres brug blev fastlagt i en tid, der fundamentalt adskilte sig fra vores, og af mennesker, hvis magt over tingene var forsvindende sammenlignet med vores. Men den forbløffende vakst, som vore hjalpemidler har oplevet m.h.t. fleksibilitet og pracision, stiller os $i$ udsigt, at der $i$ den narmeste fremtid vil ske de mest indgående andringer af den antikke virksomhed, hvorigennem det skønne er blevet fremstillet. Inden for alle kunstarter findes der en fysisk side, der ikke langere kan betragtes og behandles som tidligere; den kan ikke langere unddrage sig påvirkningerne fra den moderne viden og den moderne kraft. Hverken materien eller rummet eller tiden har $i$ de sidste tyve år varet, hvad de var fra tidernes morgen. Man må indstille sig på, at så store fornyelser vil andre hele den kunstneriske teknik, derved påvirke selv opfindelsesarbejdet og endelig måske nå dertil at andre selv kunstbegrebet på den mest fantastiske måde.
\end{abstract}

Paul Valéry: Pièces sur l'art, Paris (u.å.), p. $103 f$. (»La conquête de l'ubiquité«).

\section{Forord}

Da Marx tog fat på analysen af den kapitalistiske produktionsmåde, var denne produktionsmåde i sin begyndelse. Marx indrettede sine undersøgelser således, at de fik prognostisk værdi. Han gik tilbage til den kapitalistiske produktions grundforhold og fremstillede dem således, at det herudfra fremgik, hvad man fremover endnu ville kunne vente sig af kapitalismen. Det fremgik, at man af den ikke blot ville kunne vente sig en i stigende grad skærpet udbyt-

$K \& K 77$ (1994), 15-42 
ning af proletarerne, men til sidst også tilvejebringelsen af betingelser, som muliggør dens afskaffelse af sig selv.

Omvæltningen i overbygningen, som går meget langsommere end den, der sker i basis, har haft brug for mere end et halvt århundrede til på alle kulturområder at virkeliggøre ændringen af produktionsbetingelserne. I hvilken form dette skete, lader sig først konstatere nu. Til disse konstateringer må man stille visse prognostiske krav. Disse krav honoreres ikke så meget af teser om proletariatets kunst efter magtovertagelsen - for slet ikke at tale om kunsten i det klasseløse samfund - som af teser om kunstens udviklingstendenser under de nuværende produktionsbetingelser. Disses dialektik giver sig ikke mindre til kende i overbygningen end i økonomien. Derfor ville det være forkert at undervurdere sådanne tesers kampværdi. De sætter en række overleverede begreber til side - så som skaberkraft og genialitet, evighedsværdi og stil, form og indhold - begreber, hvis ukontrollerede (og for tiden svært kontrollerbare) brug fører til, at materialet af facts bearbejdes på en fascistisk måde. De begreber, som i det følgende indføres i kunstteorien som nye, adskiller sig fra de mere gangse derved, at de er fuldstandig uanvendelige til fascismens formål. Derimod er de anvendelige til at formulere revolutionare krav $i$ kunstpolitikken.

Kunstværket har grundlæggende altid været reproducerbart. Hvad mennesker havde fremstillet, det kunne altid gøres efter af mennesker. Efterligning på den måde blev også udført af elever som indøvelse i kunsten, af mestre til udbredelse af værkerne, endelig også af gevinstlystne tredjeparter. Derimod er den tekniske reproduktion af kunstværket noget nyt, som periodisk sætter sig igennem i historien, i ryk med stor indbyrdes afstand, men med voksende intensitet. Grækerne kendte kun to fremgangsmåder til teknisk reproduktion af kunstværker: afstøbningen og prægningen. Bronzer, terrakotta og mønter var de eneste kunstværker, som de var i stand til at fremstille i massevis. Alle andre var unikke og ikke til at reproducere teknisk. Med træsnittet blev grafik for første gang teknisk reproducerbar; den var det længe, før skriften gennem bogtrykket også blev det. De kolossale ændringer i litteraturen, som bogtrykket den tekniske reproduktion af skriften - har fremkaldt, er kendte. Af det fænomen, som her betragtes i en verdenshistorisk målestok, er det imidlertid kun et, omend et særdeles vigtigt, særtilfælde. Til træsnittet føjer sig i løbet af middelalderen kobberstikket og raderingen såvel som i begyndelsen af det 19. århundrede litografiet. 
Med litografiet når reproduktionsteknikken et fundamentalt nyt trin. Den langt mere dækkende teknik, som adskiller overførelsen af tegningen til en sten fra indskæringen af den i et stykke træ eller ætsningen af den på en kobberplade, gav for første gang grafikken muligheden for at bringe sine vidnesbyrd til markedet ikke kun massevis (som hidtil), men i dagligt nye udformninger. Grafikken blev gennem litografiet i stand til illustrativt at ledsage hverdagen. Den begyndte at kunne holde trit med bogtrykket. Allerede i denne begyndelse blev den imidlertid få årtier efter opfindelsen af stentrykket overhalet af fotografiet. Med fotografiet var hånden i den billedlige reproduktionsproces for første gang blevet frigjort fra de vigtigste kunstneriske forpligtelser, som nu udelukkende tilfaldt det $\varnothing j \mathrm{j}$, der kikkede ind i objektivet. Eftersom $\varnothing j$ jet opfatter hurtigere, end hånden tegner, så blev den billedlige reproduktionsproces fremskyndet så uhyre meget, at den kunne holde trit med talen. Filmoperatøren fixerer i atelieret med sit håndsving billederne med den samme hastighed, som skuespilleren taler med. Ligesom den illustrerede avis virtuelt lå gemt i litografiet, således gjorde tonefilmen det i fotografiet. Den tekniske reproduktion af lyden tog man fat på i slutningen af forrige århundrede. Disse konvergerende bestræbelser har sat os i stand til at overskue en situation, som Paul Valéry har beskrevet med sætningen: »Ligesom vand, gas og elektrisk strøm med et umærkeligt greb fra stor afstand kommer ind i vore boliger for at betjene os, således bliver vi forsynet med billeder eller med tonerækker, som med et lille greb, næsten kun et tegn, indfinder sig og på samme måde forlader os igen. «1 Omkring 1900 havde den tekniske reproduktion nået en standard, ud fra hvilken den begyndte ikke blot at gore totaliteten af overleverede kunstvarker til sit objekt og at underkaste deres virkning de dybeste andringer, men også erobrede sig en selvstondig plads blandt de kunstneriske teknikker. Med henblik på studiet af denne standard er intet mere oplysende, end hvorledes dens to forskellige manifestationer - reproduktionen af kunstværket og filmkunsten - virker tilbage på kunsten i dens overleverede skikkelse.

\section{II}

Selv ved den mest fuldendte reproduktion forsvinder én ting: kunstværkets her og nu - dets unikke eksistens på det sted, hvor det befinder sig. Men gennem denne unikke eksistens og ikke gennem noget andet fuldbyrdedes den historie, som det har været underkastet, så længe det har bestået. Hertil hører såvel de ændringer, det i tidens løb er undergået i sin fysiske struktur, som de skiftende ejendomsforhold, hvori det hænder at være indtrådt. ${ }^{2}$ Sporet efter de førstnævnte kan kun bringes for dagen gennem analyser af kemisk eller fysikalsk 
art, som ikke lader sig gennemføre på reproduktionen; sporet efter de sidstnævnte er genstand for en tradition, som man må forfølge med udgangspunkt i det sted, hvor originalen befinder sig.

Originalens her og nu modsvarer begrebet om dens ægthed. Kemiske analyser af en bronces patina kan tjene til at fastslå dens ægthed; tilsvarende kan påvisningen af, at et bestemt middelalderhåndskrift stammer fra et 1500-tals arkiv, fremme konstateringen af dets ægthed. Hele området vedrørende $a g$ thed unddrager sig den tekniske - og naturligvis ikke kun den tekniske - reproducerbarhed. ${ }^{3}$ Men mens det ægte har bevaret sin fulde autoritet i forhold til den manuelle reproduktion, der normalt blev stemplet som en forfalskning, er det ikke tilfældet i forhold til den tekniske reproduktion. Der er en dobbelt grund hertil. For det første viser den tekniske reproduktion sig i forhold til originalen mere selvstændig end den manuelle. Den kan eksempelvis i tilfældet med fotografiet fremhæve nogle aspekter af originalen, som kun er tilgængelige for linsen, der kan indstilles og vilkårligt vælge sit fokus, og som ikke er tilgængelige for det menneskelige øje, eller ved hjælp af visse procedurer så som forstørrelse eller slow-motion fastholde billeder, som simpelt hen unddrager sig den naturlige optik. Det er det første. Derudover kan den for det andet bringe kopien af originalen i nogle situationer, som originalen selv ikke er i stand til at nå. Frem for alt gør den det muligt at komme modtageren i møde, det være sig i skikkelse af fotografiet eller grammofonpladen. Katedralen forlader sin plads for at blive modtaget i en kunstelskers studio; korværket, som blev udført i en sal eller under fri himmel, lader sig aflytte i en stue.

De forhold, hvortil produktet af den tekniske reproduktion af kunstværket kan overføres, lader i øvrigt muligvis kunstværkets identitet uberørt - men de devaluerer under alle omstændigheder dets her og nu. Skønt det på ingen måde kun gælder kunstværket, men på samme måde f.eks. et landskab, som på film drager forbi beskueren, så berøres der i det kunstneriske objekt gennem denne fremgangsmåde en hyperfølsom kerne, der er af en sårbarhed, som ikke findes hos nogen naturlig genstand. Det er dens ægthed. En tings ægthed er indbegrebet af alt det ved den, som fra dens oprindelse kan gives videre, fra dens materielle holdbarhed til dens historiske vidnesbyrd. Da sidstnævnte er funderet i førstnævnte, så begynder i reproduktionen, hvor førstnævnte har unddraget sig mennesket, også sidstnævnte - tingens historiske vidnesbyrd at vakle. Det er ganske vist kun dette; hvad der imidlertid således begynder at vakle, er tingens autoritet. ${ }^{4}$

Hvad der her forsvinder, kan man sammenfatte i begrebet aura og sige: hvad der i kunstværkets tekniske reproducerbarheds tidsalder sygner hen, er dets aura. Processen er symptomatisk; dens betydning peger ud over kunstens område. Alment ville man kunne formulere det således, at reproduktionstek- 
nikken løsriver det reproducerede fra traditionens område. Idet reproduktionen mangfoldigg $\phi r$ den, satter den i stedet for en unik forekomst en masseforekomst. Og idet den tillader reproduktionen at komme modtageren im $\phi$ de $i$ en hvilken som helst situation, han befinder sig, aktualiserer den det reproducerede. Disse to processer fører til en voldsom rystelse af det overleverede - en rystelse af traditionen, som er bagsiden af menneskehedens nuværende krise og fornyelse. De står i den snævreste sammenhæng med massebevægelserne i vore dage. Deres mest magtfulde redskab er filmen. Dens samfundsmæssige betydning er utænkelig selv i sin mest positive form, og netop i den, uden denne dens destruktive, dens katharsiske side: likvideringen af traditionsværdien i kulturarven. Dette fænomen er mest håndgribeligt ved de store historiske film. De lægger stadig videregående positioner til deres område. Og da Abel Gance i 1927 begejstret udbrød: »Shakespeare, Rembrandt, Beethoven vil filme...Alle legender, alle mytologier og alle myter, alle religionsstiftere, ja alle religioner...venter på deres fuldt oplyste genopståen, og heltene står i trængsel ved portene, $\ll^{5}$ så har han, uden vel at mene det, indbudt til en omfattende likvidering.

\section{III}

Inden for store historiske tidsrum andrer sig i takt med de menneskelige kollektivers samlede eksistensform også arten og karakteren af deres sanseperception. Den art og måde, hvorpå den menneskelige sanseperception organiseres - det medium, hvori den finder sted - er ikke blot naturligt, men også historisk betinget. Folkevandringstiden, hvori den senromerske kunstindustri og den wienske genesis opstod, havde ikke blot en anden kunst end den antikke, men også en anden perception. Wienerskolens lærde, Riegl og Wickhoff, som opponerede mod vægten fra den klassiske overlevering, hvorunder hin kunst havde ligget begravet, er som de første kommet på den tanke herudfra at drage slutninger om perceptionen i den tid, hvori den gjorde sig gældende. Så vidtrækkende deres erkendelser end var, så havde de deres grænse deri, at disse forskere stillede sig tilfreds med at påvise den formale signatur, som særligt kendetegnede perceptionen i den senromerske tid. De har ikke fors $\emptyset \mathrm{gt}-$ kunne måske heller ikke håbe på - at påvise de samfundsmæssige omvæltninger, som fandt deres udtryk i disse ændringer i perceptionen. For nutiden foreligger der gunstigere betingelser for en sådan indsigt. Og når nogle ændringer i perceptionsmediet, hvis samtidige vi er, lader sig opfatte som auraens forfald, så kan man påvise dettes samfundsmæssige betingelser. 
Det er en god idé at illustrere det ovenfor foreslåede aurabegreb for historiske objekter ved hjælp af aurabegrebet om naturobjekter. Dette sidstnævnte definerer vi som noget fjernts unikke fremtræeden, så nært det end måtte være. Hvilende på en sommereftermiddag at følge et bjerglandskabs kontur mod horisonten eller en gren, der kaster sin skygge på den hvilende - det er at indånde disse bjerges, denne grens aura. Ved hjælp af denne beskrivelse er det en let sag at indse det nuværende auraforfalds samfundsmæssige betingethed. Det beror på to forhold, som begge hænger sammen med massernes voksende betydning i det moderne liv. Nemlig: Rumligt og menneskeligt »at bringe tingene tattere på « er et lige så lidenskabeligt anliggende for de moderne masser, ${ }^{6}$ som det er deres tendens at overvinde det unikke i enhver foreliggende kendsgerning ved at tage reproduktionen af den til sig. Dag for dag gør behovet for at kontrollere tingen helt tæt på i billedet, eller snarere i det udtrykte billede, i reproduktionen, sig stadigt mere uafviseligt gældende. Og umiskendeligt adskiller reproduktionen sig, sådan som det illustrerede blad og ugerevuen står parat med den, fra billedet. Det unikke og varigheden er i dette [billedet, o.a.] lige så snævert vævet sammen som flygtighed og gentagelighed er i hin [reproduktionen, o.a.]. Afskrælningen af det, der omgiver genstanden, nedbrydningen af auraen, er signaturen af en perception, hvis »sans for det ensartede i verden « er vokset så meget, at den ved hjælp af reproduktionen også udvinder den af det unikke. Således viser sig på det anskuelige område, hvad der på teoriens område kommer til udtryk som statistikkens voksende betydning. Tilpasningen af realiteten til masserne og af masserne til den er en proces af ubegrænset rækkevidde såvel for tænkningen som for anskuelsen.

\section{IV}

Kunstværkets unikke karakter er identisk med dets indlejring i traditionssammenhængen. Denne tradition selv er dog noget helt igennem levende, noget overordentlig foranderligt. En antik venusstatue f.eks. stod i en anden traditionssammenhæng hos grækerne, som gjorde den til genstand for kulten, end hos de middelalderlige gejstlige, som så en uheldsvanger afgud i den. Men hvad der på samme måde viste sig for dem, var den unikke karakter, med et andet ord: dens aura. Den oprindelige måde, hvorpå kunstværket var indlejret i traditionssammenhængen, fandt sit udtryk i kulten. De ældste kunstværker er, ved vi, opstået i ritualets tjeneste, først et magisk, senere et religiøst. Det er nu af afgørende betydning, at denne kunstværkets auratiske eksistensform aldrig fuldstændig løsriver sig fra dets ritualfunktion. ${ }^{7}$ Med andre ord: Det »agte« kunstvarks unikke vardi har sit fundament $i$ ritualet, hvori det havde sin op- 
rindelige og første brugsvardi. Dette fundament kan være så formidlet det være vil, det er selv i de mest profane former for skønhedskult genkendeligt som sækulariseret ritual. ${ }^{8}$ Den profane skønhedsdyrkelse, der opstår med renaissancen for siden at bevare sin betydning i tre hundrede år, afslører efter denne periode tydeligt hine fundamenter ved den første alvorlige rystelse, som rammer den.

Da kunsten med opkomsten af det første virkeligt revolutionære reproduktionsmiddel, fotografiet (samtidig med socialismens frembrud), fornemmer den optrækkende krise, som efter yderligere hundrede år nu er blevet umiskendelig, reagerede den med læren om l'art pour l'art, som er en kunstens teologi. Fra den er der så siden udgået en ligefrem negativ teologi i skikkelse af ideen om en »ren « kunst, som ikke blot afviser enhver social funktion, men også enhver bestemmelse gennem et stofligt motiv. (I digtningen er Mallarmé som den første nået til denne position.)

At lade disse sammenhænge komme til deres ret er nødvendigt for en betragtning, som har at gøre med kunstværket i dets tekniske reproducerbarheds tidsalder. Thi de forbereder den erkendelse, som her er afgørende: kunstværkets tekniske reproducerbarhed frigør for første gang i verdenshistorien dette fra dets parasitære eksistens i ritualet. Det reproducerede kunstværk bliver i stadig stigende grad reproduktionen af et kunstværk, der er beregnet til reproduktion. ${ }^{9}$ Fra den fotografiske plade eksempelvis er det muligt at lave en mangfoldighed af aftryk; spørgsmålet om det ægte aftryk har ingen mening. Men i det øjeblik, hvor aggthedskriteriet ikke laengere slår til $i$ kunstproduktionen, har kunstens hele sociale funktion forvandlet sig. I stedet for dens fundering $i$ ritualet trader dens fundering $i$ en anden praksis: nemlig dens fundering i politik.

\section{V}

Receptionen af kunstværket sker med forskellige accenter, hvoriblandt to hinanden modsatrettede træder frem. Den ene af disse accenter ligger på kunstværkets kultværdi, den anden på dets udstillingsværdi. ${ }^{10,11}$ Den kunstneriske produktion begynder med frembringelser, som står i kultens tjeneste. Ved disse frembringelser er det vigtigere, at de er til stede, end at de bliver set. Elsdyret, som stenaldermennesket afbilder på væggene i sin hule, er et trylleinstrument. Han udstiller det ganske vist for sine medmennesker; først og fremmest er det imidlertid tiltænkt ånderne. Kultværdien synes i dag ligefrem at tendere til at holde kunstværket i det skjulte: visse gudebilleder er kun tilgængelige for præsten i cella, visse madonnabilleder forbliver næsten hele året 
dækket til, visse skulpturer i middelalderlige domkirker er ikke synlige for betragtere, der befinder sig på gulvniveau. Med frigфrelsen af de enkelte former for kunstud $\phi v e l s e$ fra ritualets sk $\phi d$ vokser mulighederne for udstillingen af deres produkter. Muligheden for at udstille en portrætbuste, som kan sendes både her og der, er større end for en gudestatue, som har sin faste plads i templets indre. Tavlebilledets udstillingsmulighed er større end mosaikkens eller freskoens, som gik forud for det. Og selv om en messes udstillingsmulighed oprindelig måske ikke var ringere end en symfonis, så opstod symfonien dog på det tidspunkt, hvor dens udstillingsmulighed tegnede til at blive større end messens.

Med de forskellige metoder til teknisk reproduktion af kunstværket er dettes udstillingsmulighed vokset i så voldsomt et omfang, at den kvantitative forskydning mellem dets to poler ligesom i urtiden slår over i en kvalitativ ændring af dets natur. Ligesom kunstværket nemlig i urtiden i kraft af den absolutte vægt, der lå på dets kultværdi, i første række blev til et instrument for magien, som man på sin vis først senere anerkendte som kunstværk, således bliver kunstværket i kraft af den absolutte vægt, som ligger på dets udstillingsværdi, til en frembringelse med helt nye funktioner, hvoriblandt den for os bevidste, den kunstneriske, træder frem som den, man senere måske vil erkende som forbigående. ${ }^{12}$ Så meget er sikkert, at aktuelt giver fotografiet og endvidere filmen de mest anvendelige holdepunkter for denne erkendelse.

\section{$V I$}

I fotografiet begynder udstillingsvaerdien over hele linien at trange kultvardien tilbage. Denne viger imidlertid ikke modstandsløst. Den besætter en sidste forskansning, og det er menneskeansigtet. Det er ingenlunde tilfældigt, at portrættet står i centrum for det tidlige fotografi. I dyrkelsen af erindringen om de fjerne eller de afdøde har billedets kultværdi den sidste tilflugt. I et menneskeansigts flygtige udtryk vinker ud af de tidlige fotografier auraen for sidste gang. Det er det, som udgør deres melankolske og med intet sammenlignelige skønhed. Men hvor mennesket trækker sig ud af fotografiet, da træder udstillingsværdien for første gang kultværdien overlegent imøde. At have givet denne proces dens steder er den uforlignelige betydning som tilkommer Atget, der omkring år 1900 fastholdt parisergaderne i mennesketomme vuer. Med megen ret har man sagt om ham, at han fotograferede dem som et gerningssted. Også gerningsstedet er mennesketomt. Fotograferingen af det finder sted for indiciernes skyld. De fotografiske optagelser begynder hos Atget at blive bevismidler i den historiske proces. Det udgør deres skjulte politiske betydning. De 
kræver i sig selv en reception på en bestemt måde. Over for dem er den fritsvævende kontemplation ikke længere passende. De foruroliger betragteren; han føler: til dem må han søge en bestemt vej. Samtidig begynder de illustrerede blade at opstille vejvisere for ham. Rigtige eller forkerte - det er lige meget. I dem er billedtekster for første gang blevet obligate. Og det er klart, at de har en ganske anden karakter end titlen på et maleri. De direktiver, som billedbetragteren modtager i det illustrerede blad igennem billedteksterne, bliver kort derefter endnu præcisere og mere bydende i filmen, hvor opfattelsen af hvert enkelt billede synes at være foreskrevet af rækkefølgen i alle de forudgående.

\section{VII}

Den strid, som i løbet af det nittende århundrede blev udkæmpet mellem maleriet og fotografiet om kunstværdien af deres produkter, virker i dag hen $\mathrm{i}$ vejret og forvirret. Det taler imidlertid ikke mod dens betydning, kunne måske snarere understrege den. I realiteten var denne strid udtryk for en verdenshistorisk omvæltning, der som sådan ikke var nogen af de to parter bevidst. Idet den tidsalder, der gjorde kunsten teknisk reproducerbar, løste den fra dens kultiske fundament, ophørte for altid skinnet af dens autonomi. Men kunstens funktionsændring, som var givet dermed, faldt uden for århundredets synsfelt. Og også det tyvende århundrede, som oplevede udviklingen af filmen, undgik den længe.

Havde man tidligere brugt meget forgaves skarpsind på at afgфre spфrgsmålet, om fotografiet var en kunst - uden at have stillet sig det forudgående spфrgsmål: om ikke kunstens totalkarakter havde andret sig i kraft affotografiets opfindelse - så overtog filmteoretikerne snart den tilsvarende forhastede problemstilling. Men de vanskeligheder, som fotografiet havde beredt den overleverede æstetik, var barneleg i forhold til dem, som ventede den i forbindelse med filmen. Heraf den blinde voldsomhed, som kendetegner filmteoriens tidlige begyndelse. Således sammenligner Abel Gance f.eks. film med hieroglyfferne: »Således er vi da, som følge af en højst mærkværdig tilbagevenden til det fortidige, igen nået til ægypternes udtryksniveau... Billedsproget er endnu ikke nået til modning, fordi vore øjne endnu ikke er det voksent. Der er endnu ikke nok agtelse, ikke nok kult over for det, som kommer til udtryk i den. « ${ }^{13}$ Eller Séverin-Mars skriver: »Hvilken kunst var en drøm beskåret, som ... kunne have været mere poetisk og på samme tid virkeligere! Betragtet fra et sådant synspunkt ville filmen udgøre et helt usammenligneligt udtryksmiddel, og det burde kun være tilladt personer af den ædleste tænkemåde i de 
mest fuldendte og hemmelighedsfulde $\varnothing j$ jeblikke af deres livsbane at bevæge sig i dens atmosfære. $\ll^{14}$ Alexandre Arnoux afslutter for sit vedkommende en fantasi om stumfilmen direkte med spørgsmålet: »Burde ikke alle de dristige beskrivelser, som vi her har betjent os af, løbe ud i definitionen af bønnen? «15 Det er meget lærerigt at se, hvordan bestræbelsen på at gøre filmen til en del af kunsten tvinger disse teoretikere til at indtolke kultiske elementer i den med en hensynsløshed uden lige. Og dog forelå der på det tidspunkt, hvor disse spekulationer blev offentliggjort, allerede værker som »L'Opinion publique« og »La ruée vers l'or.« Det forhindrer ikke Abel Gance i at inddrage sammenligningen med hieroglyfferne, og Séverin-Mars taler om filmen, som man kunne tale om billeder af Fra Angelico. Det er kendetegnende, at selv i dag søger især reaktionære forfattere efter filmens betydning i samme retning og om ikke direkte i det sakrale så dog i det overnaturlige. I anledning af Reinhardts filmatisering af En Skcersommernatsdrøm fastslår Werfel, at det uden tvivl var den sterile kopi af den ydre verden med dens gader, interieurs, banegårde, restauranter, biler og badestrande, som indtil da havde stået i vejen for, at filmen kunne svinge sig op i kunstens rige. »Filmen har endnu ikke fattet sin sande mening, sine virkelige muligheder... De består i dens enestående evne til med naturlige midler og med uforlignelig overbevisningskraft at bringe det feagtige, forunderlige, overnaturlige til udtryk. ${ }^{16}$

\section{VIII}

Definitivt bliver sceneskuespillerens kunstpræstation præsenteret af denne selv i egen person over for publikum; derimod bliver filmskuespillerens kunstpræstation præsenteret for publikum gennem et apparatur. Det sidstnævnte har to ting til følge. Det apparatur, som bringer filmskuespillerens præstation frem for publikum, er ikke forpligtet til at respektere denne præstation som totalitet. Styret af kameramanden tager det løbende stilling til denne præstation. Rækkefølgen af indstillinger, som filmklipperen komponerer ud af det materiale, han får leveret, udgør den færdigmonterede film. Den omfatter et vist antal bevægelsesmomenter, der må erkendes som kameraets - for ikke tale om specialindstillinger såsom nærbilleder. Således bliver skuespillerens præstation underkastet en række optiske test. Dette er den første konsekvens af den omstændighed, at filmskuespillerens præstation bliver præsenteret ved hjælp af apparaturet. Den anden konsekvens beror på, at filmskuespilleren, da han ikke selv præsenterer sin præstation for publikum, mister den mulighed, som sceneskuespilleren er i besiddelse af, at tilpasse sin præstation efter publikum i løbet af forestillingen. Dette kommer derved til at indtage holdningen som en skøns- 
mand, der ikke forstyrres af nogen form for personlig kontakt med skuespilleren. Publikum indføler sig kun i skuespillleren, idet det føler sig ind i apparatet. Det overtager altså dettes holdning: det tester.$^{17}$ Det er ingen holdning, som kultværdier kan udsættes for.

IX

For filmen kommer det meget mindre an på, at skuespilleren over for publikum spiller en anden, end at han over for apparaturet spiller sig selv. En af de første, som har fornemmet denne forandring af skuespilleren i kraft af testpræstationen, har været Pirandello. Det gør kun lidt afbræk i de bemærkninger, som han gør herom i sin roman Der filmes, at de begrænser sig til at fremhæve den negative side af sagen. Endnu mindre, at de knytter an til stumfilmen. For tonefilmen har intet grundlæggende ændret ved denne sag. Det forbliver afgørende, at der spilles for et apparatur - eller i tilfældet med tonefilmen, for to. »Filmskuespilleren«, skriver Pirandello, »føler sig som i exil. Exileret ikke blot fra scenen, men fra sin egen person. Med et dunkelt ubehag fornemmer han den uforklarlige tomhed, som opstår ved, at hans krop bliver til et forsvindende fænomen, at han forflygtiges, og at han berøves sin realitet, sit liv, sin stemme og de lyde, han fremkalder, når han bevæger sig, for at forvandle sig til et stumt billede, som sitrer et øjeblik på lærredet og så forsvinder...Det lille apparatur vil spille med hans skygge foran publikum; og han selv må nøjes med at spille foran det. $\ll^{18}$ Man kan beskrive det samme faktiske forhold på følgende måde: for første gang - og det er filmens værk - kommer mennesket i den situation at måtte virke ganske vist med sin hele levende person, men med afkald på dennes aura. For auraen er bundet til dets her og nu. Der findes ingen afbildning af den. Den aura, der på scenen er omkring Macbeth, kan ikke løsrives fra den, der for det levende publikum er omkring den skuespiller, som spiller ham. Men det ejendommelige ved optagelsen i filmatelieret består i, at den i stedet for publikum sætter apparaturet. Således må den aura, som er omkring skuespilleren, falde bort - og samtidig også den, der er omkring den fremstillede figur.

At netop en dramatiker som Pirandello i karakteristikken af filmen uvilkårligt berører grunden til den krise, som vi ser ramme teatret, er ikke overraskende. Til det kunstværk, som restløst indbefattes af den tekniske reproduktion, ja - som filmen - stammer herfra, findes der faktisk ikke nogen mere decideret modsætning end teaterscenen. Enhver mere indgående betragtning bekræfter dette. Sagkyndige iagttagere har for længst erkendt, at i skuepil på film »opnås de største virkninger næsten altid ved at man 'spiller' så lidt som 
muligt...Den seneste udvikling«, ser Arnheim i 1932 i, at »behandle skuespilleren som en rekvisit, som man udvælger efter karaktertype og...indsætter på det rigtige sted. $\ll{ }^{19}$ Hermed hænger noget andet på den snævreste måde sammen. Skuespilleren, der agerer på scenen, rykker ind i en rolle. Det er meget ofte nagtet filmskuespilleren. Hans præstation udgør slet ikke nogen enhed, men er sammensat af mange enkeltpræstationer. Ud over tilfældige hensyn til atelierleje, rådigheden over partnere, kulisser o.s.v. er det maskineriets elementære nødvendigheder, som splitter skuespillerens spil op i en række monterbare episoder. Det drejer sig frem for alt om belysningen, hvis anvendelse tvinger fremstillingen af en handling, der på lærredet fremtræder som et enhedsligt, hurtigt forløb, til at blive tilvejebragt i en række enkeltoptagelser, som i atelieret undertiden kan strække sig over timer. For ikke at tale om de mere håndgribelige montager. Således kan et spring ud af vinduet $\mathrm{i}$ et atelier optages i form af et spring fra et stillads, den derpå følgende flugt om nødvendigt ugevis senere i en udendørsoptagelse. I $\varnothing$ vrigt er det en let ting at konstruere langt mere paradoksale tilfælde. Det kan blive krævet af en skuespiller, at han, efter at det har banket på døren, farer sammen. Måske er denne faren sammen ikke faldet ud som ønsket. Da kan instruktøren gribe til den udvej ved lejlighed, når skuespilleren igen er i atelieret, at lade et skud affyre bag hans ryg, uden at han ved det i forvejen. Skuespillerens forskrækkelse i dette øjeblik kan optages og monteres ind i filmen. Intet viser mere drastisk, at kunsten er forduftet fra »den skønne illusions « område, som i så lang tid har været anset for det eneste sted, hvor den kunne trives.

X

Skuespillerens undren foran apparaturet, som Pirandello skildrer den, er fra starten af den samme slags som den undren, mennesket føler over for sin egen fremtoning i spejlet. Men nu er spejlbilledet blevet uafhængigt af mennesket, det er blevet transportabelt. Og hvor bliver det transporteret hen? Hen foran publikum. ${ }^{20}$ Bevidstheden herom forlader ikke filmskuespilleren et $\varnothing$ jeblik. Filmskuespilleren ved, mens han står foran apparaturet, at han i sidste ende har at gфre med publikum: publikummet af aftagere, som udgфr markedet. Dette marked, som han begiver sig ind på ikke kun med sin arbejdskraft, men med hud og hår, med hjerte og nyrer, er for ham i det øjeblik, hvor han skal yde den ham tiltænkte præstation, lige så uhåndgribeligt, som det er for en hvilken som helst artikel, der bliver fremstillet på en fabrik. Mon ikke denne omstændighed har sin andel i den beklemthed, den ny angst, som ifølge Pirandello griber skuespilleren foran apparaturet? Filmen reagerer på auraens 
indskrumpning med en kunstig opbygning af »personality « uden for atelieret. Den stjernedyrkelse, som filmkapitalen fremelsker, konserverer den personlighedens fortryllelse, som forlængst kun eksisterer i den fade fortryllelse, dens varekarakter indeholder. Så længe filmkapitalen slår tonen an, kan man i almindelighed ikke tillægge filmen i dag nogen anden revolutionær fortjeneste, end at den fremmer en revolutionær kritik af overleverede forestillinger om kunst. Vi bestrider ikke, at filmen i dag derudover i særlige sammenhæng kan fremme en revolutionær kritik af de samfundsmæssige forhold, ja af ejendomsforholdene. Men i nærværende undersøgelse ligger vægten lige så lidt på dette punkt, som den gør det i den vesteuropæiske filmproduktion.

Det hænger sammen med filmteknikken nøjagtigt som med sporten, at enhver overværer de præstationer, der bliver udstillet, som halvvejs fagmand. Man behøver kun én gang have hørt en gruppe avisbude, støttet til deres cykler, diskutere begivenhederne i et cykelløb for at få øjnene op for dette faktum. Det er ikke omsonst, at avisudgivere arrangerer væddel $\varnothing \mathrm{b}$ for deres bude. Disse vækker stor interesse blandt deltagerne. For sejrherren i disse arrangementer har en chance for at stige op fra avisbud til cykelrytter. Ligeledes giver eksempelvis ugerevuen enhver en chance for at stige op fra forbipasserende til filmstatist. Han kan på denne måde i nogle tilfælde se sig flyttet ind i et kunstværk - man kan tænke på Vertovs Tre sange om Lenin eller Ivens Borinage. Ethvert nutidigt menneske kan gøre fordring på at blive filmet. Bedst tydeliggøres denne fordring af et blik på den aktuelle litteraturs historiske situation.

I århundreder var situationen i litteraturen, at et lille antal skrivende stod over for et mange tusinde gange større antal læsende. Heri indtrådte der mod slutningen af forrige århundrede en forandring. Med den voksende udbredelse af pressen, som til stadighed stillede nye politiske, religiøse, videnskabelige, erhvervsmæssige, lokale organer til rådighed for læserne, kom stadig større dele af læserne - til at begynde med lejlighedsvis - ind blandt de skrivende. Det startede med, at dagspressen åbnede sin »brevkasse« for dem, og det ligger i dag sådan, at der næppe findes en erhvervsaktiv europæer, som ikke fundamentalt ville kunne finde lejlighed til et eller andet sted at publicere en arbejdserfaring, en klage, en reportage eller lignende. På denne måde er forskellen mellem forfatter og publikum i færd med at miste sin grundlæggende karakter. Den bliver en funktionel forskel, der fra situation til situation forløber på den ene eller den anden måde. Den læsende er til enhver tid klar til at blive en skrivende. Som sagkyndig, hvilket han med eller mod sin vilje må blive i en yderst specialiseret arbejdsproses - om det så kun er som sagkyndig $i$ en ubetydelig form for beskæftigelse -, vinder han adgang til at blive forfatter. I Sovjetunionen kommer arbejdet selv til orde. Og den verbale formulering af det udgør en del af den kunnen, som kræves for at udøve det. Den litterære 
kompetence grundlægges ikke mere i den specialiserede, men i den polytekniske uddannelse og er således et alment gode. ${ }^{21}$

Alt dette lader sig uden videre overføre på filmen, hvor forskydninger, som i litteraturen har taget århundreder, er blevet fuldbyrdet i løbet af et årti. For i filmens praksis - frem for alt den russiske - er denne forskydning stedvis allerede blevet virkeliggjort. En del af de skuespillere, man møder i den russiske film, er ikke skuespillere i vores forstand, men folk, som spiller sig selv - og det vil sige i første række i deres arbejdsproces. I Vesteuropa forbyder den kapitalistiske udbytning af filmen, at man tager hensyn til det legitime krav, som mennesket af i dag har på at blive reproduceret. Under disse omstændigheder har filmindustrien al mulig interesse $i$ at anspore massernes deltagelse ved hjælp af illusionære forestillinger og ved hjælp af tvetydige spekulationer.

XI

En film og især en tonefilmoptagelse frembyder et syn, som det aldrig tidligere eller nogetsteds har kunnet tænkes. Den udgør en proces, som ikke kan ses fra et eneste synspunkt, uden at det optageapparatur, belysningsmaskineri, assistenstab o.s.v., som ikke hører til spilleprocessen som sådan, kommer ind i tilskuerens synsfelt. (Det skulle da lige være, hvis indstillingen af hans pupil svarer til kameraets.) Mere end nogen anden gør denne omstændighed de måske eksisterende ligheder mellem en scene i filmatelieret og på teatret overfladiske og uvæsentlige. Teatret kender principielt det sted, hvorfra handlingsgangen ikke uden videre kan gennemskues som illusionær. I forhold til optagelsesscenen i filmen findes dette sted ikke. Dens illusionære natur er en natur af anden grad; den er et resultat af klipningen. Det vil sige: $i$ filmatelieret er apparaturet $i$ den grad trangt ind $i$ virkeligheden, at det rene syn på den, frit for apparaturets fremmedlegeme, er resultatet af en scerlig procedure, nemlig af optagelsen ved hjolp af det til formået indstillede apparat og denne optagelses sammenklipning med andre optagelser af samme art. Det apparatfrie syn på realiteten er her blevet til det mest kunstige og betragtningen af den umiddelbare virkelighed til den blå blomst i teknikkens land.

Samme sagsforhold, der på denne måde adskiller sig fra teatrets, lader sig med endnu større udbytte konfrontere med det, der foreligger i maleriet. Her må vi stille spørgsmålet: hvordan forholder filmoperatøren sig til maleren? For at svare på det må det være tilladt at bruge en hjælpekonstruktion, som støtter sig på det begreb om operatøren, som er almindeligt kendt fra kirurgien. Kirurgen udgør den ene pol i en orden, i hvilken magikeren står ved den anden. Holdningen hos magikeren, der helbreder en syg ved håndspålæggelse, er for- 
skellig fra holdningen hos kirurgen, der foretager et indgreb i den syge. Magikeren opretholder den naturlige distance mellem sig selv og den behandlede; rettere sagt: han formindsker den - i kraft sin pålagte hånd - kun lidt og forøger den - i kraft af sin autoritet - meget. Kirurgen går omvendt til værks: han formindsker i høj grad distancen til den behandlede - idet han trænger ind i dennes indre -, og han forøger den kun lidt - i kraft af den varsomhed, hvormed hans hånd bevæger sig mellem organerne. Kort sagt: til forskel fra magikeren (som der endnu stikker noget af i den praktiserende læge) afstår kirurgen i det afgørende $\varnothing$ jeblik fra at stille sig over for sin patient som menneske til menneske; han trænger snarere operativt ind i ham. - Magikeren og kirurgen forholder sig til hinanden som maleren og kameramanden. Maleren iagttager i sit arbejde en naturlig distance til det, han står over for, kameramanden derimod trænger dybt ind i de foreliggende kendsgerningers væv. ${ }^{22}$ De billeder, som de to tager med sig, er uhyre forskellige. Malerens er et totalbillede, kameramandens et mangfoldigt fragmenteret billede, hvis dele finder sammen igen efter en ny lov. Således er den filmiske fremstilling af virkligheden for menneskene i dag usammenligneligt mere betydningsfuld, fordi den giver det apparatfri syn på virkeligheden, som mennesket er berettiget til at krave af kunstvarket, netop på grund af, at apparaturet gennemtraenger fremstillingen på den mest konsekvente vis.

\section{XII}

Kunstvarkets tekniske reproducerbarhed andrer massens forhold til kunsten. Fra det mest tilbagestående, f.eks. over for en Picasso, slår det om til det mest progressive, f.eks. over for en Chaplin. I denne forbindelse er den progressive holdning kendetegnet ved, at lysten til at se og til at opleve indgår en umiddelbar og inderlig forbindelse med den fagkyndiges holdning. En sådan forbindelse er et vigtigt samfundsmæssigt indicium. Jo mere nemlig en kunsts samfundsmæssige betydning svinder, desto mere falder - som det tydeligt har vist sig over for maleriet - den kritiske og den nydende holdning hos publikum fra hinanden. Det konventionelle bliver nydt kritikløst, det virkeligt nye kritiserer man med modvilje. I biografen falder publikums kritiske og nydende holdning sammen. Og den afgørende omstændighed i den forbindelse er denne: den enkeltes reaktioner, hvis sum udgør publikums massereaktion, viser sig intetsteds mere end i biografien fra første færd at være betinget af, at den umiddelbart derefter indgår i massereaktionen. Og idet reaktionerne viser sig, kontrollerer de hinanden. Også videre frem forbliver sammenligningen med maleriet nyttig. Maleriet havde vedvarende en særlig fordring på at blive betragtet af en 
eller få. Et stort publikums simultane betragtning af malerier, som det kommer op i det nittende århundrede, er et tidligt symptom på maleriets krise, som ingenlunde kun blev udløst af fotografiet, men relativt uafhængigt heraf af kunstværkets fordring på massepublikummet.

Det forholder sig nu engang sådan, at maleriet ikke er i stand til at frembyde et objekt for en simultan kollektiv reception, som det fra tidernes morgen gjaldt for arkitekturen, tidligere for eposet, og som det i dag gælder for filmen. Og så lidt som man ud fra dette forhold kan drage slutninger om maleriets samfundsmæssige rolle, så vejer det dog tungt som en begrænsning i det øjeblik, hvor maleriet under særlige omstændigheder og på sin vis mod dets natur bliver konfronteret umiddelbart med masserne. I middelalderens kirker og klostre og ved fyrstehofferne indtil hen mod slutningen af det attende århundrede fandt den kollektive reception af malerier ikke sted simultant, men blev ordnet og hierarkisk formidlet. Når det nu er blevet anderledes, så kommer her den særlige konflikt til udtryk, hvori maleriet er blevet fanget i kraft af billedets tekniske reproducerbarhed. Men selv om man fik arrangeret, at de blev ført frem for masserne i gallerier og i saloner, så fandtes der dog ingen måde, hvorpå masserne i en sådan reception ville kunne organisere og kontrollere sig selv. ${ }^{23}$ Således må det selv samme publikum, som reagerer progressivt over for en grotesk film, blive tilbagestående over for surrealismen.

\section{XIII}

Filmen har sine karakteristika ikke blot i den måde, hvorpå mennesket stiller sig frem for optageapparaturet, men også i den måde, hvorpå han med dettes hjælp fremstiller omverdenen. Et blik på præstationspsykologien illustrerer apparaturets evne til at teste. Et blik på psykoanalysen illustrerer den fra en anden side. Filmen har faktisk beriget vores sensoriske verden med metoder, som kan illustreres med den freudske teoris metoder. En fejl i samtalen passerede for halvtreds år siden mere eller mindre ubemærket. At den på én gang åbnede et dybdeperspektiv i samtalen, som tidligere syntes at forløbe i forgrunden, skulle tælles blandt undtagelserne. Siden Hverdagslivets psykopatologi har det ændret sig. Den har isoleret ting og samtidig gjort dem analyserbare, som tidligere ubemærket flød med i det perciperedes brede strøm. Filmen har over hele den optiske sanseverdens bredde, og nu også den akustiske, resulteret i en lignende fordybelse af perceptionen. Det er kun bagsiden af dette sagsforhold, at de præstationer, som filmen lægger frem, kan analyseres langt mere eksakt og under langt talrigere synspunkter end de præstationer, som fremtræder på maleriet eller på teatret. I forhold til maleriet er det den 
usammenligneligt mere præcise angivelse af situationen, som udgør den i filmen fremstillede præstations større analyserbarhed. I forhold til teatret er den filmisk fremstillede præstations større analyserbarhed betinget af en højere isolerbarhed. Denne omstændighed har - og det udgør dens hovedbetydning tendens til at fremme kunstens og videnskabens gensidige gennemtrængning. Faktisk lader det sig næppe mere angive om en adfærd, som i en bestemt situation nøgternt - som en muskel på en krop - er præpareret frem, hvorved den fængsler mest: i kraft af sin kunstneriske værdi eller i kraft sin videnskabelige nyttighed. Det bliver en af filmens revolutionare funktioner at få den kunstneriske og videnskabelige anvendelse af fotografiet, som tidligere oftest faldt fra hinanden, til at traede frem som identisk. ${ }^{24}$

Idet filmen gennem forstørrelser af dens inventardele, gennem fremhævelse af skjulte detaljer ved de for os gængse rekvisitter, gennem udforskning af banale milieuer under objektivets geniale ledelse, på den ene side forøger indsigten i de tvangsmæssigheder, som vores eksistens styres af, kommer den på den anden side til at love os et uhyre og uanet spillerum! Vore beværtninger og storbygader, vore kontorer og møblerede værelser, vore banegårde og fabrikker syntes at lukke os inde uden håb. Da kom filmen og har med tiendedelssekundernes dynamit sprængt denne fængselsverden, så vi nu helt roligt foretager eventyrlige rejser blandt dens vidtspredte ruiner. Under forstørrelsen udvider rummet sig, under slow motion bevægelsen. Og så lidt som det ved forstørrelsen drejer sig om blot at tydeliggøre det, som man »i forvejen «ser utydeligt, men snarere om at fuldstændig nye strukturdannelser i materien kommer til syne, så lidt bringer slow motion blot kendte bevægelsesmotiver til syne, men derimod afslører den i disse kendte nogle helt ukendte, »som virker slet ikke som hurtige bevægelser, der bliver sagtnet, men som ejendommeligt glidende, svævende, overjordiske bevægelser. $\aleph^{25}$ På denne måde bliver det håndgribeligt, at det er en anden natur, som taler til kameraet end til øjet. Anderledes først og fremmest derved, at der i stedet for et af mennesket bevidst gennemvirket rum træder et ubevidst gennemvirket. Selv om det allerede er almindeligt, at man gør sig klart, hvordan folk går, omend det blot er i grove træk, så ved man bestemt intet om deres holdning i den brøkdel af et sekund, hvor de skridter ud. Er vi i grove træk fortrolige med den bevægelse, vi gør, når vi rækker ud efter fyrtøjet eller skeen, så ved vi dog næppe, hvad der i den forbindelse egentlig foregår mellem hånden og metallet, for ikke at tale om hvordan det varierer med de forskellige tilstande, vi befinder os i. Her griber kameraet ind med sine hjælpemidler, sin nedadgående og sin opadgående bevægelse, sin afbryden og sin isoleren, sin udvidelse og sin sammentrækning af forløbet, sin forstørren og sin formindsken. Først gennem kameraet opdager vi det optisk ubevidste, som gennem psykoanalysen det driftsmæssigt ubevidste. 
Det har altid været en af kunstens vigtigste opgaver at skabe en efterspørgsel, til hvis fulde tilfredsstillelse tiden endnu ikke er kommet. ${ }^{26}$ Hver kunstforms historie indeholder kritiske tidspunkter, hvor denne form tenderer mod effekter, som først opstår uden besvær ved en ændret teknisk standard, d.v.s. i en ny kunstform. De extravagancer og grovheder i kunsten, som opstår på denne måde især i de såkaldte forfaldstider, udgår i virkeligheden fra dens rigeste historiske kraftcentrum. Senest har dadaismen bugnet af sådanne barbarismer. Dens impuls hertil kan først nu erkendes: Dadaismen fors $\phi$ gte med maleriets hjalpemidler (hhv. litteraturens) at producere de effekter, som publikum i dag sф ger i filmen.

Enhver fra grunden af ny, banebrydende frembringelse af efterspørgsel vil skyde over målet. Dadaismen gør det i den grad, at den ofrer de markedsværdier, som i så høj grad kendetegner filmen, til fordel for vigtigere intentioner - som den naturligvis ikke er bevidst om i den her beskrevne udformning. Dadaisterne lagde langt mindre vægt på deres kunstværkers merkantile anvendelighed end på deres uanvendelighed til kontemplativ fordybelse. Denne uanvendelighed søgte de ikke mindst at opnå ved hjælp af en grundlæggende nedvurdering af deres materiale. Deres digte er »ordsalat «, de indeholder obskøne vendinger og alt overhovedet tænkeligt sprogligt affald. Det er ikke anderledes med deres malerier, hvorpå de monterede knapper og billetter. Hvad de opnår med sådanne midler, er en hensynsløs tilintetgørelse af auraen ved deres produkter, som de med produktionens midler påfører en reproduktions brændemærke. Over for et billede af Arp eller et digt af August Stramm er det umuligt at give sig tid til koncentration og stillingtagen som over for et billede af Derain eller et digt af Rilke. Over for fordybelsen, som under borgerskabets udarten blev til en skole i asocial adfærd, træder adspredelsen som en form for social adfærd. ${ }^{27}$ I realiteten garanterede de dadaistiske manifestationer en ret kraftig adspredelse, idet de gjorde kunstværket til midtpunkt for en skandale. Det skulle frem for alt tilfredsstille én fordring: at vække offentlig forargelse.

Fra et lokkende syn eller et overtalende klangbillede blev kunstværket hos dadaisterne til et projektil. Det ramte betragteren. Det fik en taktil kvalitet. På denne måde har det fremmet efterspørgslen efter filmen, hvis adspredende element ligledes i første række er taktilt, d.v.s. beror på skiften mellem scener og indstillinger. Man kan sammenligne lærredet, på hvilket filmen kører, med det lærred, hvorpå maleriet befinder sig. Det sidste opfordrer betragteren til kontemplation; foran det kan han give sig hen til sit associationsforløb. Det kan han ikke foran filmoptagelsen. Næppe har han taget den i øjesyn, før den allerede har ændret sig. Den kan ikke fixeres. Duhamel, som hader filmen, og som 
har begrebet intet af dens betydning, men meget af dens struktur, registrerer dette forhold med følgende notits: »Jeg kan snart ikke mere tænke, hvad jeg $\emptyset$ nsker at tænke. De bevægelige billeder har taget mine tankers plads. $\aleph^{28}$ Faktisk bliver associationsforløbet hos den, som betragter disse billeder, straks afbrudt gennem ændringen af dem. Herpå beror filmens chokvirkning, der som enhver chokvirkning må blive modsvaret af intensiveret åndsnærvær. ${ }^{29} I$ kraft af sin tekniske struktur har filmen befriet den fysiske chokvirkning, som dadaismen så at sige endnu holdt indpakket i den moralske, for denne emballage. ${ }^{30}$

\section{$X V$}

Massen er en matrix, hvorfra enhver vant holdning til kunstværker i vore dage udgår påny. Kvantiteten er slået om i kvalitet: De langt større masser af deltagende har frembragt en andret måde at deltage på. Det bør ikke forvirre betragteren, at denne deltagelse i første omgang viser sig i en tvivlsom skikkelse. Det har dog ikke manglet på dem, der lidenskabeligt har holdt sig til netop denne overflade ved sagen. Heriblandt har Duhamel ytret sig mest radikalt. Hvad han især fortænker filmen i, er den form for deltagelse, som den fremkalder hos masserne. Han kalder filmen »et tidsfordriv for heloter, en adspredelse for udannede, elendige, nedslidte kreaturer, som fortæres af deres bekymringer...et skuespil, som ikke kræver nogen form for koncentration, ikke forudsætter nogen tænkeevne..., ikke tænder noget lys i hjerterne og ikke vækker anden forhåbning end den latterlige en dag at blive 'star' i Los Angeles. $\ll^{31}$ Man ser, at det i grunden er den gamle klage over, at masserne søger adspredelse, men at kunsten kræver koncentration af betragteren. Det er en trivialitet. Tilbage står kun spørgsmålet, om den giver en basis for undersøgelsen af filmen. - Her gælder det om at se nøjere efter. Adspredelse og koncentration står i en modsætning, der tillader følgende formulering: den, der over for et kunstværk koncentrerer sig, fordyber sig i det; han går ind i dette værk, sådan som legenden fortæller om en kinesisk maler, da han betragtede sit fuldendte billede. I modsætning hertil lader den adspredte masse på sin side kunstværket synke ned i sig. Mest tydeligt bygningsværker. Arkitekturen har altid repræsenteret prototypen på et kunstværk, hvis reception sker i adspredthed og i den kollektive sammenhæng. Lovene for reception heraf er de mest lærerige.

Bygninger har ledsaget menneskeheden siden dens ældste historie. Mange kunstformer er opstået og er forsvundet. Tragedien opstår med grækerne for at svinde bort med dem og efter århundreder blot at genopstå som »reglerne« for den. Eposet, hvis oprindelse ligger i folkenes ungdom, ophører i Europa med 
udgangen af renaissancen. Tavlemaleriet er en middelalderlig frembringelse, og intet garanterer det en fortsat varighed. Men menneskets behov for tag over hovedet er vedvarende. Bygningskunsten har aldrig ligget brak. Dens historie er længere end enhver anden kunsts, og at anskueliggøre dens virkning er vigtigt for ethvert fors $\varnothing \mathrm{g}$ på at redegøre for massernes forhold til kunstværket. Bygninger bliver reciperet på en dobbelt måde: gennem brug og gennem betragtningen af dem. Eller bedre formuleret: taktilt og optisk. Der findes ikke noget begreb om en sådan reception, hvis man forestiller sig den svarende til den samlede reception, som er gængs for f.eks. turister over for berømte bygningsværker. Der findes nemlig på den taktile side intet modstykke til det, som på den optiske er kontemplationen. Den taktile reception sker ikke så meget via opmærksomheden som via vanen. I forhold til arkitektur bestemmer den sidstnævnte ovenikøbet langthen den optiske reception. Også den sker oprindeligt langt mindre i spændt opmærksomhed end i en lejlighedsvis registreren. Men denne reception, som formes i relation til arkitekturen, har under visse omstændigheder kanonisk værdi. Thi: De opgaver, som i historiske brydningstider bliver stillet det menneskelige perceptionsapparat, kan slet ikke loses via den blotte optik, altså kontemplation. De kan klares lidt efter lidt med hjoelp fra den taktile reception, gennem tilvanning.

Også den adspredte kan vænne sig til noget. Eller rettere: at kunne klare visse opgaver, mens man er adspredt, viser først, at det er blevet en vane at løse dem. Gennem adspredtheden, sådan som kunsten kan tilbyde den, bliver det under hånden kontrolleret, $\mathrm{i}$ hvilket omfang nye perceptionsopgaver er blevet til at løse. Da der for den enkelte for $\emptyset$ vrigt eksisterer fristelsen til at unddrage sig sådanne opgaver, så vil kunsten tage fat på de sværeste og vigtigste af disse, hvor den kan mobilisere masserne. Den gør det i vore dage i filmen. Den adspredte reception, som med voksende eftertryk viser sig på alle kunstens områder, og som er et symptom på dybtgående andringer i perceptionen, har i filmen sit egentlige фveinstrument. Med sin chokvirkning kommer filmen denne receptionsform imøde. Filmen trænger ikke kun kultværdien tilbage derved, at den bringer publikum til at indtage en vurderende holdning, men også derved, at den vurderende holdning i biografen ikke omfatter opmærksomhed. Publikum er en eksaminator, men en adspredt sådan.

\section{Efterskrift}

Den tiltagende proletarisering af vore dages mennesker og den tiltagende formering af masser er to sider af én og samme proces. Fascismen fors $\varnothing$ ger at organisere de nyligt proletariserede masser uden at antaste de ejendomsfor- 
hold, som de presser på for at afskaffe. Den ser sin frelse i at lade masserne komme til udtryk (men absolut ikke til deres ret). ${ }^{32}$ Masserne har en ret til ændring af ejendomsforholdene; fascismen søger at give dem et udtryk under bevaring af disse forhold. Fascismen forer følgelig til en oestetisering af det politiske liv. Undertrykkelsen af masserne, som den i en førerkult tvinger til jorden, svarer til undertrykkelsen af et apparatur, som den udnytter til frembringelse af kultværdier.

Alle bestrabelser på at aestetisere politikken kulminerer $i$ ét punkt. Dette ene punkt er krigen. Krigen, og kun krigen, gør det muligt at give massebevægelser i den helt store målestok et mål samtidig med, at de overleverede ejendomsforhold bliver bevaret. Det ser situationen ud set fra en politisk synsvinkel. Inden for teknikken ser den ud på følgende måde: kun krigen gør det muligt at mobilisere alle vore dages tekniske hjælpemidler under opretholdelse af ejendomsforholdene. Det siger sig selv, at krigens apoteose igennem fascismen ikke betjener sig af disse argumenter. Alligevel er et blik på dem lærerigt. I Marinettis manifest til den ætiopiske kolonikrig hedder det: »I nu syvogtyve år har vi futurister talt imod, at krigen betegnes som antiæstetisk...I overensstemmelse hermed slår vi fast:... Krigen er smuk, fordi den takket være gasmaskerne, de skrækindjagende megafoner, flammekasterne og de små tanks lægger grunden til menneskets beherskelse af den undertvungne maskine. Krigen er smuk, fordi den indvarsler den metallisering af den menneskelige krop, som man har drømt om. Krigen er skøn, fordi den beriger en blomstrende eng med maskingeværernes glødende orkidéer. Krigen er skøn, fordi den forener geværilden, kanonaderne, ildpauserne, duftene og forrådnelseslugtene til en symfoni. Krigen er skøn, fordi den skaber ny arkitektoniske former, så som de store tanks, de geometriske flyeskadriller, røgspiralerne fra brændende landsbyer og meget andet...Futurismens digtere og kunstnere...husk disse grundsætninger i en krigens æstetik, så jeres kamp for en ny poesi og en ny plastik ... kan blive inspireret af dem! «33

Dette manifest har den fordel at være tydeligt. Dets problemstilling fortjener at blive overtaget af dialektikeren. For ham fremtræder den moderne krigs æstetik således: holdes den naturlige udnyttelse af produktivkræfterne tilbage af ejendomsforholdene, så frempresser forbedringen af de tekniske hjælpemidler, af tempiene, af energikilderne en unaturlig udnyttelse. Den finder den i krigen, der med sine ødelæggelser leverer beviset for, at samfundet endnu ikke var modent til at gøre teknikken til sit redskab, at teknikken ikke var udviklet tilstrækkeligt til at beherske de samfundsmæssige elementarkræfter. Den imperialistiske krig er i sine mest grufulde træk determineret af diskrepansen mellem de vældige produktionsmidler og den utilstrækkelige udnyttelse af dem i produktionsprocessen (med andre ord af arbejdsløsheden og mangelen 
på afsætningsmarkeder). Den imperialistiske krig er et oprør fra teknikken, som på »menneskematerialet « satter de fordringer igennem, som samfundet har berфvet deres naturlige materiale. I stedet for at kanalisere floder leder den menneskestrømmen ned i sine skyttegraves flodleje, i stedet for at strø frø ud fra sine flyvemaskiner, strør den brandbomber ned over byerne, og i gaskrigen har den fundet et middel til på en ny måde at afskaffe auraen.

»Fiat ars - pereat mundus «, siger fascismen og forventer, som Marinetti bekender, fra krigen den kunstneriske tilfredsstillelse af den af teknikken ændrede sanseperception. Det er åbenlyst fuldbyrdelsen af l'art pour l'art. Menneskeheden, som engang hos Homer var et skueobjekt for de olympiske guder, er nu blevet det for sig selv. Dens selvfremmedgørelse har nået en sådan grad, at dens egen tilintetgørelse lader sig opleve som æstetisk nydelse af første rang. Således forholder det sig med den astetisering af politikken, som fascismen bedriver. Kommunismen svarer den med politiseringen af kunsten.

Oversat fra »Das Kunstwerk im Zeitalter seiner technischen Reproduzierbarkeit« (»Zweite Fassung «), in Walter Benjamin: Gesammelte Schriften, I.2, Frankfurt a.M. 1974, pp. 471-508. Oversattelsen er blevet gennemset af docent, dr. E.-U.Pinkert, Aalborg, som har ydet stor og beredvillig hjcelp til forståelsen af mange vanskelige passager, hvilket jeg takker meget for. Ansvaret for den endelige ordlyd og de fejl og uheldigheder, den måtte indeholde, er dog naturligvis alene mit.

Jørgen Holmgaard

\section{Noter}

1. Paul Valéry: Pièces sur l'art, Paris u.å., p.105 (»La conquête de l'ubiquité«).

2. Naturligvis omfatter kunstværkets historie endnu mere: Mona Lisas historie f.eks. arten og antallet af de kopier, som blev lavet i det syttende, attende, nittende århundrede.

3. Netop fordi ægtheden ikke er reproducerbar, har den intensive udvikling af visse tekniske - reproduktionsprocesser frembragt redskaber til differentiering og graduering af ægtheden. At udvikle sådanne former for skelnen var en af kunsthandelens vigtige funktioner. Denne havde en håndgribelig interesse $\mathrm{i}$ at adskille forskellige aftryk af en træstok - før og efter skriften - fra en kobberplade og lignende. Man kan sige, at med opfindelsen af træsnittet var ægthedskvaliteten angrebet ved roden, før den endnu havde udfoldet sin sene blomstring. »Ægte« var et middelalderligt madonnabillede jo endnu ikke på det tidspunkt, det blev lavet; det blev det i løbet af de efterfølgende århundreder og mest omfattende måske i forrige.

4. Den jammerligste provinsopførelse af Faust har i hvert fald det fortrin frem for en Faust-film, at den idealt står i konkurrence med uropførelsen i Weimar. Og hvad man m.h.t. traditionelt indhold kan genkalde sig foran rampen, er foran filmlærredet blevet ubrugeligt - at Goethes ungdomsven Johann Heinrich Merck gemmer 
sig i Mephisto m.m. af den slags.

5. Abel Gance: »Le temps de l'image est venu«, in: L'art cinématographique II, Paris 1927, p.94-96.

6. Menneskeligt at lade sig bringe tættere på masserne kan betyde: at lade sin samfundsmæssige funktion forsvinde ud af synsfeltet. Intet garanterer, at en moderne portrætmaler, når han maler en berømt kirurg ved frokostbordet og $\mathrm{i}$ familiens skød, rammer dennes samfundsmæssige funktion mere præcist end en maler i det 16. århundrede, der fremstiller sine læger repræsentativt foran publikum, som f.eks. Rembrandt i »Anatomien.

7. Definitionen af auraen som »noget fjernts unikke fremtræden, så nært det end er« beskriver intet andet end formuleringen af kunstværkets kultværdi i den rum-tidslige perceptions kategorier. Fjernhed er modsætningen til nærhed. Det vaesensmassigt fjerne er det utilnærmelige. Faktisk er utilnærmelighed en hovedkvalitet ved kultbilledet. Det forbliver ifølge sin natur »noget fjernt, så nært det end måtte være.«Den nærhed, som man er i stand til at aftvinge dets materie, gør ikke noget afbræk i fjernheden, som det bevarer efter sin fremtræden.

8. I det omfang, billedets kultværdi bliver sækulariseret, bliver forestillingerne om substratet i dets unikke karakter mere ubestemte. I stadig højere grad bliver det unikke i den i kultbilledet herskende fremtræden fortrængt af billedkunstnerens empirisk unikke karakter eller af hans billedskabende præstation, sådan som den opfattes hos modtageren. Men det sker ikke restløst; begrebet om ægthed ophører aldrig med at tendere ud over den autentiske tilskrivning. (Det viser sig særligt tydelig hos samleren, der stadig bevarer noget af fetichdyrkeren i sig, og som gennem sin besiddelse af kunstværket har andel i dettes kultiske kraft.) Uanset dette forbliver autenticitetsbegrebets funktion i kunstbetragtningen entydig: med sækulariseringen af kunsten træder autenticiteten i kultværdiens sted.

9. Ved filmværker er produktets tekniske reproducerbarhed ikke som ved f.eks. litteratur- eller maleriværker en udefra kommende betingelse for deres masseudbredelse. Filmvarkernes tekniske reproducerbarhed er grundlagt direkte i deres produktionsteknik. Denne muliggфr ikke blot på den mest direkte måde masseudbredelse af filmvarkerne, den ligefrem fremtvinger den snarere. Den fremtvinger den, fordi produktionen af en film er så dyr, at en enkelt, der f.eks. ville have råd til et maleri, ikke længere har råd til filmen. I 1927 har man beregnet, at en større film for at forrente sig må nå et publikum på ni millioner. Med tonefilmen er der tilmed her i første omgang sket et tilbageslag; dens publikum blev begrænset af sproggrænser, og det skete samtidig med betoningen af de nationale interesser gennem fascismen. Vigtigere end at registrere dette tilbageslag, som i øvrigt blev svækket gennem synkroniseringen, er det at se dets sammenhæng med fascismen i øjnene. Samtidigheden mellem de to fænomener skyldes den $\emptyset$ konomiske krise. De samme forstyrrelser, som i den store sammenhæng har ført til forsøget på at fastholde de bestående ejendomsforhold med åben vold, har ført den krisetruede filmkapital til at fremskynde forarbejderne til tonefilmen. Indførelsen af tonefilmen bragte således en midlertidig lettelse. Og det ikke kun fordi tonefilmen påny førte masserne ind i biografen, men også fordi tonefilmen gjorde nye kapitaler fra den elektriske industri solidariske med filmkapitalen. Således har den udefra betragtet fremmet nationale interesser, men indefra betragtet internationaliseret filmproduktionen endnu mere end tidligere.

10. Denne polaritet kan ikke komme til sin ret i idealismens æstetik, hvis begreb om skønhed fundamentalt indbefatter den som udelt (og følgelig udelukker den som 
delt). Alligevel giver den sig hos Hegel så tydeligt til kende, som dette kan tænkes inden for idealismens grænser. »Billeder«, hedder det i forelæsningerne over historiefilosofien, »havde man allerede længe haft: fromheden havde brug for dem til sin andagt, men den behøvede ingen smukke billeder, ja disse var ovenikøbet forstyrrende for den. I det smukke billede foreligger der også noget ydre, men for så vidt som det er smukt, taler dettes ånd til menneskene; i hin andagt er forholdet til en ting imidlertid væsentligt, thi den er selv kun en åndløs sløvning af sjælen...Den skønne kunst er...opstået i kirken selv,...skønt...kunsten allerede da er trådt ud af kirkens princip«, Georg Wilhelm Friedrich Hegel: Werke. Vollständige Ausgabe durch einen Verein von Freunden des Verewigten. Bd.9: Vorlesungen über die Philosophie der Geschichte. Hrsg. von Eduard Gans. Berlin 1837, p.414. Også et sted i forelæsningerne over æstetikken peger på, at Hegel her har anet et problem. »...vi er«, hedder det i forelæsningerne, »kommet ud over at kunne ære kunstværker religiøst og tilbede dem, det indtryk, som de gør, er af en mere rolig karakter, og det, som de vækker i os, kræver en højere prøvesten«, Hegel op.cit., bd.10: Vorlesungen über die Aesthetik, Hrsg. von H.G.Hotho. Bd.1, Berlin 1835, p.14.

11. Overgangen fra den første type kunstnerisk reception til den anden bestemmer overhovedet det historiske forløb i den kunstneriske reception. Desuagtet lader en vis skiften mellem de to polære receptionstyper sig principielt påvise for hvert enkelt kunstværk. Således f.eks. for den sixtinske madonna. Siden Hubert Grimmes undersøgelse ved man, at den sixtinske madonna oprindeligt blev malt til udstillingsformål. Grimme fik tilskyndelsen til sine undersøgelser gennem spørgsmålet: Hvad skal trælisten i forgrunden af billedet, hvortil de to putti støtter sig? Hvorledes kunne, spurgte Grimme videre, en Rafael komme på at udstyre himlen med et sæt portierer? Undersøgelsen viste, at den sixtinske madonna var blevet givet i opdrag i anledning af pave Sextus' lit de parade. Pavernes lit de parade fandt sted i et bestemt sidekapel i Peterskirken. Hvilende på kisten var Rafaels billede ved den højtidelige lit de parade blevet anbragt i den nicheagtige baggrund af dette kapel. Hvad Rafael fremstiller på dette billede, er, hvorledes madonnaen fra den af grønne portierer afgrænsede niche omgivet af skyer nærmer sig den pavelige kiste. Ved begravelseshøjtideligheden for Sextus fandt en fremragende udstillingsværdi i Rafaels billede sin anvendelse. Nogen tid derefter blev det flyttet til højaltret i sortebrødrenes klosterkirke i Piacenza. Grunden til denne flytning ligger i det romerske ritual. Det romerske ritual forbyder at bringe billeder, som har været udstillet ved bisættelseshøjtideligheder, ind i højalterkulten. Rafaels værk var i kraft af denne forskrift i et vist omfang blevet devalueret. For alligevel at opnå en passende pris for det besluttede kurien sig til at give sin stiltiende accept af billedet på højalteret med i købet. For at undgå opsigt lod man billedet gå til broderskabet i den fjerntliggende provinsby.

12. Brecht anstiller på et andet plan analoge overvejelser: »Kan man ikke mere opretholde begrebet kunstværk om den ting, der opstår, når et kunstværk bliver forvandlet til vare, så må vi forsigtigt og omhyggeligt, men uforskrækket opgive dette begreb, hvis vi ikke samtidig selv vil likvidere denne tings funktion, for den må igennem denne fase, og det uden bagtanker, der er ingen uforbindtlig smutvej fra den rette vej, men det, der her sker med den, det vil ændre den fra grunden, udslette dens fortid, så meget, at hvis det gamle begreb igen ville blive taget op - og det vil det blive, hvorfor ikke? - vil der ikke derigennem blive udløst en erindring om den ting, som det engang betegnede, « Bertolt Brech: Versuche 8-10 [hæfte] 3, Berlin 1931, p.301 f; »Der Dreigroschenprozess.« 
13. Abel Gance, loc.cit., p.100 f.

14. Citeret efter Abel Gance, loc.cit., p.100.

15. Alexandre Arnoux: Cinéma, Paris 1929, p.28.

16. Franz Werfel: »En Skærsommernatsdrøm. En film af Shakespeare og Reinhardt«, in Neues Wiener Journal, citeret efter $L u, 15$. november 1935.

17. »Filmen...giver (eller kunne give): anvendelige oplysninger om menneskelige handlinger ned i detaljen...Enhver motivering med udgangspunkt i karakteren mangler, personernes indre liv giver aldrig hovedårsagen og er sjældent hovedresultatet af handlingen«, Brecht loc.cit., p.268. Den udvidelse af det testbares område, som apparaturet bringer tilveje i forhold til filmskuespilleren, svarer til den overordentlige udvidelse af det testbares område, som er indtrådt for individet $\mathrm{i}$ kraft af de $\varnothing$ konomiske omstændigheder. Således vokser betydningen af erhvervsegnethedsprøver vedvarende. Ved erhvervsegnethedsprøven kommer det an på udsnit af individets præstation. Filmoptagelse og erhvervsegnethedsprøve foregår i et forum af fagfolk. Lederen af optagelserne i filmatelieret står præcis på det sted, hvor forsøgslederen står ved egnethedsprøven.

18. Luigi Pirandello: On tourne, citeret efter Léon Pierre-Quint: »Signification du cinéma«, in L'art cinématographique II, op.cit., p.14 f.

19. Rudolf Arnheim: Film als Kunst, Berlin 1932, p.176 f. - Visse tilsyneladende uvæsentlige detaljer, hvormed filminstruktøren fjerner sig fra praksis på scenen, får i denne sammenhæng en $\emptyset$ get interesse. Således fors $\emptyset$ get på at lade skuespilleren spille uden sminke, som bl.a. Dreyer gennemførte i Jeanne d'Arc. Han brugte måneder på at finde frem til de omkring fyrre skuespillere, som indgår i kætterdomstolen. Jagten på disse skuespillere lignede jagten på rekvisitter, som er svære at skaffe. Dreyer brugte stor anstrengelse på at undgå ligheder i alder, statur, fysiognomi, jf. Maurice Schultz, »Le Masquilllage«, in L'art cinématographique, VI, Paris 1929, p. 65 f. Når skuespilleren bliver til rekvisit, så fungerer på den anden side rekvisitten ikke sjældent som skuespiller. I hvert fald er der intet usædvanligt $\mathrm{i}$, at filmen kommer i den situation, at den giver rekvisitten en rolle. I stedet for at gribe fat i et tilfældigt eksempel ud fra en uendelig mangfoldighed holder vi os til et med særlig beviskraft. Et ur, der går, vil på scenen altid virke forstyrrende. Man kan ikke på scenen tillade, at det får den rolle at måle tiden. I et naturalistisk stykke ville den astronomiske tid også kollidere med den sceniske. Under disse omstændigheder er det højst betegnende for filmen, at den lejlighedsvis uden videre kan værdsætte urets tidsmåling. Herigennem kan man tydeligere end gennem mange andre træk erkende, hvordan enhver enkelt rekvisit under visse omstændigheder kan få afgørende funktioner. Herfra er der kun et skridt til Pudowkins konstatering, at »skuespillerens spil, som sker forbundet med en genstand og er opbygget herpå,...stadig er en af de stærkeste metoder i filmisk gestaltning «, cf. W.Pudowkin: Filmregie und Filmmanuskript [Bücher der Praxis, bd.5] Berlin 1928, p.126. Således er filmen den første kunstart, som er i stand til at vide, hvordan materien spiller sammen med mennesket. Den kan derfor være et fremragende instrument til en materialistisk fremstilling.

20. Den her konstaterbare ændring af udstillingsmåden i kraft af reproduktionsteknikken træder også frem i politikken. De borgerlige demokratiers krise indbefatter de betingelser, som bestemmer den måde, hvorpå de regerende bliver udstillet. Demokratierne udstiller den regerende umiddelbart i egen person og ovenikøbet frem for repræsentanter. Parlamentet er hans publikum! Med de fornyelser i optagelsesapparaturet, som gør det muligt, at den talende høres af ubegrænset mange, mens 
han taler, og kort tid efter ses af ubegrænset mange, træder det politiske menneskes optræden foran dette optageapparatur i forgrunden. Det lægger parlamenterne $\varnothing$ de på samme tid som teatrene. Radio og film ændrer ikke kun den professionelle skuespillers funktion, men præcis på samme måde påvirker de den, der som de regerende $\mathrm{g} \varnothing \mathrm{r}$ det, fremstiller sig selv foran disse apparater. Retningen i denne ændring er, uanset deres forskellige specielle opgaver, den samme hos filmskuespilleren og hos den regerende. Den stræber efter at opstille kontrollerbare, ja overførlige præstationer under bestemte samfundsmæssige betingelser. Det resulterer i en ny selektion, en selektion foran apparaturet, som stjernen og diktatoren går ud af som sejrherrer.

21. De pågældende teknikkers privilegiekarakter går tabt. Aldous Huxley skriver: »De tekniske fremskridt har....ført til vulgaritet...den tekniske reproducerbarhed og rotationspressen har muliggjort en uendelig mangfoldiggørelse af skrifter og billeder. Den almene skoleuddannelse og de forholdsmæssigt høje lønninger har skabt et meget stort publikum, som kan læse og er i stand til at skaffe sig læsestof og billedmateriale. For at tilfredsstille dette er en betydelig industri blevet etableret. $\mathrm{Nu}$ er kunstnerisk begavelse imidlertid noget sjældent; heraf følger..., at den overvejende del af den kunstneriske produktion til enhver tid og alle steder er blevet mindre værd. I dag er procentsatsen af ragelse i den kunstneriske produktionsproces blevet større, end den nogensinde før har været...Vi står her over for et enkelt aritmetisk sagsforhold. I løbet af det sidste århundrede er Vesteuropas befolkning vokset til godt det dobbelte. Læse- og billedstoffet er imidlertid vokset, så vidt jeg kan skønne, mindst i forholdet fra 1 til 20, men måske også til 50 eller til 100. Hvis en befolkning på x millioner har $\mathrm{n}$ kunstneriske talenter, så vil en befolkning på $2 \mathrm{x}$ millioner sandsynlighed have $2 \mathrm{n}$ kunstneriske talenter. $\mathrm{Nu}$ kan man sammenfatte situationen på følgende måde. Mens man for 100 år siden offentliggjorde én trykside med læse- og billedstof, så offentliggør man til gengæld i dag tyve, om ikke hundrede sider. Mens der for hundrede år siden eksisterede ét kunstnerisk talent, så eksisterer der i stedet i dag to. Jeg indrømmer, at som følge af den almene skoleuddannelse vil i dag et stort antal mulige talenter, som tidligere ikke ville have fået udfoldelse af deres gaver, kunne blive produktive. Lad os således antage..., at der i dag går tre eller endog fire kunstneriske talenter på ét kunstnerisk talent tidligere. Det forbliver ikke desto mindre ubetvivleligt, at forbruget af læse- og billedstof langt har overhalet den naturlige produktion af begavede forfattere og begavede tegnere. Det forholder sig ikke anderledes med det, man hører. Velstanden, grammofonen og radioen har kaldt et publikum til live, hvis forbrug af lytterstof er uden forhold til væksten i befolkningen og følgelig til den normale vækst i antallet af talentfulde musikere. Resultatet heraf er altså, at i alle kunstarter, såvel absolut som forholdsmæssigt, er produktionen af ragelse større end den tidligere var; og således må det blive ved med at være, så længe folk fortsætter som nu at praktisere et uforholdsmæssigt stort forbrug af læse-, billed- og lyttestof, « Aldous Huxley: Croisière d'hiver. Voyage en Amérique centrale (1933), oversat af Jules Castier, Paris 1935, p.273-75. Denne betragtningsmåde er åbenlyst ikke progressiv.

22. Kameramandens dristighed kan i virkeligheden sammenlignes med kirurgens. Luc Durtain opregner i en fortegnelse over teknikkens specifikt gestiske kunststykker dem, »som kræves inden for kirurgien ved visse vanskelige indgreb. Jeg vælger som eksempel et tilfælde fra oto-rhino-laryngologien...; jeg mener det såkaldte endonasale perspektivindgreb; eller jeg kan henvise til de akrobatiske kunststykker, som strubehovedkirurgien, styret af det omvendte billede i strubehovedspejlet, har 
udført; jeg ville også kunne nævne ørekirurgiens præcisionsarbejde, som minder om urmagernes. Hvilken righoldig skala af yderst subtil muskelakrobatik kræves ikke af den, som vil reparere eller redde den menneskelige krop, man kan blot tænke på stæroperationen, hvor der foregår en slags debat mellem stålet og nogle næsten flydende vævsdele, eller på de betydningsfulde indgreb i bughulen (laporotomi), « Luc Durtain: »La technique et l'homme«, in Vendredi, 13.3. 1936, no.19.

23. Denne betragtningsmåde kan forekomme plump; men som den store teoretiker Leonardo viser, kan plumpe betragtningsmåder meget vel inddrages, når tidspunktet er til det. Leonardo sammenligner maleriet og musikken med følgende ord: »Maleriet er musikken overlegen af den grund, at det ikke må dø, så snart det bliver kaldt til live, som det er tilfældet med den ulykkelige musik...Musikken, der flygter, såsnart den er opstået, står tilbage for maleriet, som med brugen af fernis er blevet evigt.« [Leonardo da Vinci: »Frammenti letterarii e filosofici«], cit. efter Fernand Baldensperger: »La raffermissement des techniques dans la littérature occidentale de 1840« in Revue de Littérature Comparée, XV/I, Paris 1935, p.79 [anm.1].

24. Søger vi efter en analogi til denne situation, så åbner der sig en oplysende sådan i renaissancemaleriet. Også der møder vi en kunst, hvis uforlignelige opsving og hvis betydning ikke mindst beror på, at den integrerer en række nye videnskaber eller i hvert fald nye data fra videnskaben. Den trækker på anatomien og perspektivet, matematikken, meteorologien og farvelæren. »Hvad er os mere fjernt«, skriver Valéry, »end den påfaldende fordring hos en Leonardo, for hvem maleriet var et overordnet mål og en højeste demonstration af erkendelse, tilmed i den grad at det efter hans overbevisning krævede alvidenhed, og at han ikke selv veg tilbage for en teoretisk analyse, som vi i dag står målløse over for grundet dens dybde og præcision.«Paul Valéry: Pièces sur l'art, op.cit., p.191, »Autour de Corot.«

25. Rudolf Arnheim, op.cit., p.138.

26. »Kunstværket«, siger André Breton, »har kun værdi, for så vidt som det er gennembævet af fremtidens reflekser.« Faktisk står enhver reflekteret kunstform i skæringspunktet mellem tre udviklingslinier. For det første arbejder teknikken nemlig i retning af en bestemt kunstform. Før filmen kom op, fandtes små fotobøger, hvis billeder ved et tryk med tommelfingeren hurtigt pilede forbi betragteren og viste en bokse- eller tenniskamp; i basarerne fandtes automater, hvis billedforl $\varnothing$ b blev fremkaldt, ved at man drejede på et håndsving. - For det andet arbejder de overleverede kunstformer i visse stadier af deres udvikling anstrengt hen mod effekter, som senere uden besvær opnås af den ny kunstform. Før filmen slog igennem, forsøgte dadaisterne gennem deres arrangementer at tilføre publikum en bevægelse, som en Chaplin derpå fremkaldte på en mere naturlig måde. - For det tredje arbejder ofte næppe synlige, samfundsmæssige ændringer hen mod en ændring af receptionen, som først kommer den nye kunstform tilgode. Før filmen havde begyndt at danne sit publikum, blev billeder (som allerede var ophørt med at være ubevægelige) i »Kaiserpanorama« reciperet af et forsamlet publikum. Dette publikum befandt sig foran en skærm, hvori der var anbragt stereoskoper, ét til hver gæst. Foran disse stereoskoper viste sig automatisk enkeltbilleder, som kort stod stille og derefter gjorde plads for andre. Med lignende midler måtte endda Edison arbejde, da han viste den første filmstrimmel (før man kendte et filmlærred og projektionsteknikken) for et lille publikum, som stirrede ind i apparatet, hvori billedrækken rullede gennem. - I øvrigt kommer der i indretningen af »Kaiserpanorama« særlig klart en udviklingsdialektik til udtryk. Kort før filmen gør betragtningen af billeder til et 
kollektivt fænomen, manifesterer sig foran stereoskoperne i disse hurtigt forældede etablissementer den enkeltes billedbetragtning med samme skarphed, som den tidligere gjorde det i præstens betragtning af gudebilledet i cella.

27. Det teologiske urbillede på denne fordybelse er bevidstheden om at være alene med sin Gud. I borgerskabets store perioder blev friheden til at afryste det kirkelige formynderi styrket af denne bevidsthed. I dets nedgangsperioder måtte den samme bevidsthed tage hensyn til den skjulte tendens til at unddrage fællesskabsanliggenderne de kræfter, som den enkelte sætter i værk i omgangen med Gud.

28. Georges Duhamel: Scènes de la vie future, 2.udg., Paris 1930, p.52.

29. Filmen er den kunstform, som svarer til den forøgede livsfare, som vore dages mennesker må se i øjnene. Behovet for at udsætte sig for chokvirkninger er menneskenes tilpasning til de farer, som truer dem. Filmen modsvarer dybtgående ændringer i perceptionsapparatet - ændringer, sådan som enhver trafikant i storbytrafikken oplever dem inden for rammerne af sin private eksistens, såvel som enhver nutidig samfundsborger oplever dem i en historisk ramme.

30. Ligesom det gælder for dadaismen, kan man også for kubismen og futurismen drage vigtige slutninger fra filmen. Begge fremtræder som utilstrækkelige fors $\emptyset \mathrm{g}$ fra kunstens side på at tage hensyn til gennemtrængningen af virkeligheden ved hjælp af apparaturet. Disse skoler foretog til forskel fra filmen deres fors $\varnothing \mathrm{g}$ ikke ved at opprioritere apparaturet m.h.p. den kunstneriske fremstilling af virkeligheden, men gennem en slags legering af fremstillet virkelighed og fremstillet apparatur. I denne forbindelse spiller i kubismen anelsen om konstruktionen af dette apparatur, som beror på optikken, den vigtigste rolle; i futurismen er det anelsen om virkningerne af dette apparatur, som kommer til udtryk i filmstrimlens hurtige afspilning.

31. Duhamel, loc.cit., p.58.

32. Her er et teknisk forhold af betydning, især med henblik på ugerevuen, hvis propagandistiske værdi næppe kan overvurderes. Massereproduktionen kommer i sarlig grad reproduktionen af masserne i møde. I de store festoptog, i mammutforsamlingerne, i massearrangementerne af sportslig art og i krigen, som i vore dage alle føres frem for optagelsesapparatet, ser massen sig selv i ansigtet. Denne proces, hvis rækkevidde ikke behøver at understreges, hænger på det snævreste sammen med udviklingen af reproduktions- hhv. optagelsesteknikken. Massebevægelser fremtræder generelt tydeligere for apparaturet end for blikket. Kadrer på hundredetusinder lader sig bedst opfatte fra fugleperspektiv. Og selv om dette perspektiv er tilgængeligt for øjet såvel som for apparaturet, så kan det billede, som øjet tager med sig derfra, ikke forstørres, sådan som man kan gøre med fotooptagelsen. Det vil sige, at massebevægelserne, og således også krigen, repræsenterer en form for menneskelig adfærd, der i særlig grad kommer apparaturet i møde.

33. Citeret efter La Stampa, Torino. 
